
Not for reproduction, distribution or commercial use.

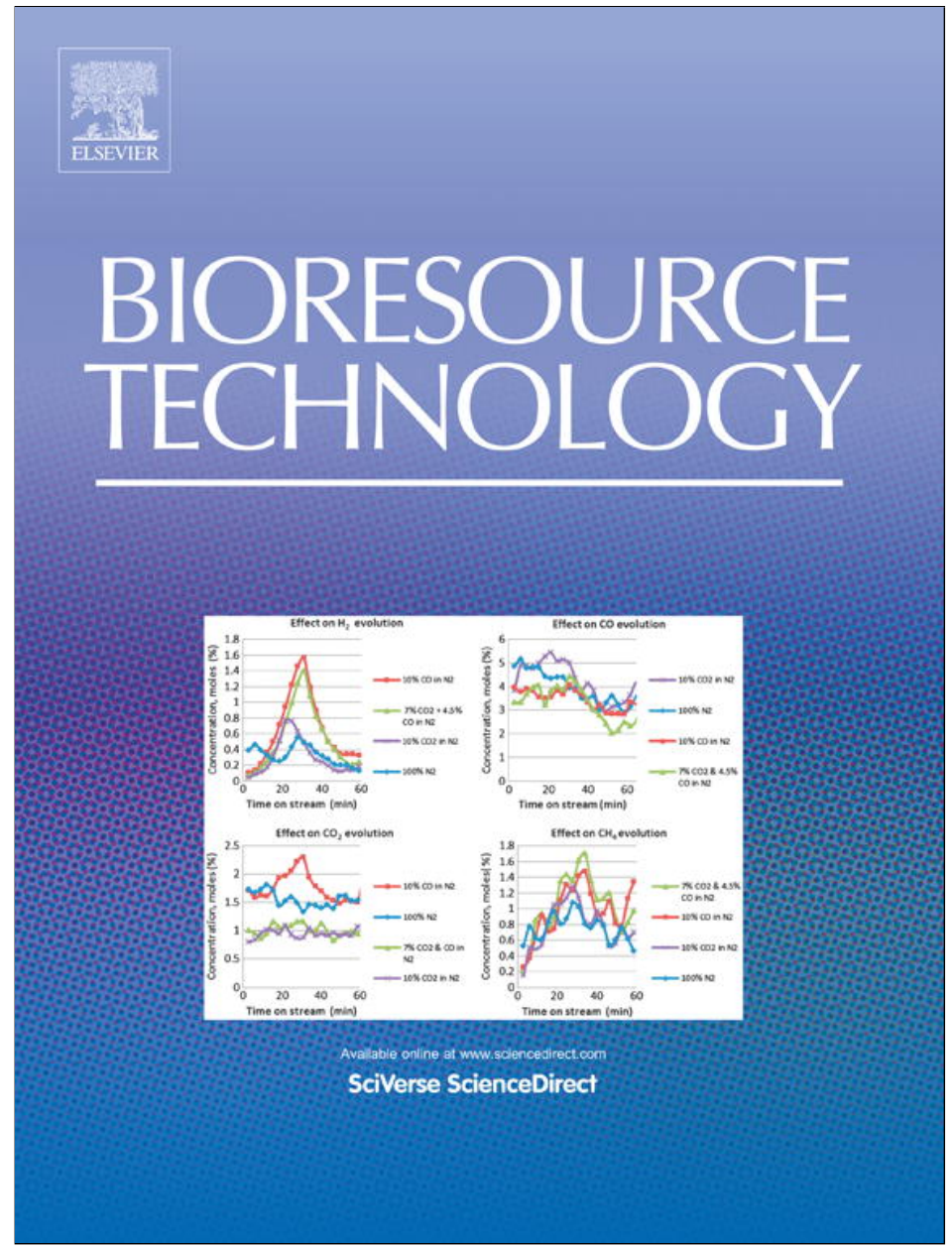

(This is a sample cover image for this issue. The actual cover is not yet available at this time.)

This article appeared in a journal published by Elsevier. The attached copy is furnished to the author for internal non-commercial research and education use, including for instruction at the authors institution and sharing with colleagues.

Other uses, including reproduction and distribution, or selling or licensing copies, or posting to personal, institutional or third party websites are prohibited.

In most cases authors are permitted to post their version of the article (e.g. in Word or Tex form) to their personal website or institutional repository. Authors requiring further information regarding Elsevier's archiving and manuscript policies are encouraged to visit: 


\title{
Anaerobic biodegradability of Category 2 animal by-products: Methane potential and inoculum source
}

\author{
Tatiana A. Pozdniakova ${ }^{a}$, José C. Costa ${ }^{\text {b }}$, Ricardo J. Santos ${ }^{a}$, M.M. Alves ${ }^{\text {b }}$, Rui A.R. Boaventura ${ }^{a, *}$ \\ ${ }^{a}$ LSRE - Laboratory of Separation and Reaction Engineering - Associate Laboratory LSRE/LCM, Faculdade de Engenharia, Universidade do Porto, \\ Rua Dr. Roberto Frias, Porto 4200-465, Portugal \\ ${ }^{\mathrm{b}}$ IBB - Institute for Biotechnology and Bioengineering, Centre of Biological Engineering, Universidade do Minho, Campus de Gualtar, Braga 4710-057, Portugal
}

\section{H I G H L I G H T S}

- Methane production from animal by-products is affected by the inoculum source.

- Landfill leachate and sludge from anaerobic lagooning are good inoculum sources.

- The maximum methane production rate is $35 \mathrm{~mL} \mathrm{CH}_{4} \mathrm{~g}^{-1} \mathrm{VS}_{\text {substrate }} \mathrm{d}^{-1}$.

- The biodegradability of Category 2 animal by-products is inhibited at 5\% TS.

\section{A R T I C L E I N F O}

\section{Article history:}

Received 22 May 2012

Received in revised form 3 August 2012

Accepted 6 August 2012

Available online 17 August 2012

\section{Keywords:}

Animal by-products

Anaerobic digestion

Solids concentration

Gompertz model

Inoculum source

\begin{abstract}
A B S T R A C T
Category 2 animal by-products that need to be sterilized with steam pressure according Regulation (EC) $1774 / 2002$ are studied. In this work, 2 sets of experiments were performed in mesophilic conditions: (i) biomethane potential determination testing $0.5 \%, 2.0 \%$ and $5.0 \%$ total solids (TS), using sludge from the anaerobic digester of a wastewater treatment plant as inoculum; (ii) biodegradability tests at a constant TS concentration of $2.0 \%$ and different inoculum sources (digested sludge from a wastewater treatment plant; granular sludge from an upflow anaerobic sludge blanket reactor; leachate from a municipal solid waste landfill; and sludge from the slaughterhouse wastewater treatment anaerobic lagoon) to select the more adapted inoculum to the substrate in study. The higher specific methane production was of $317 \mathrm{~mL}$ $\mathrm{CH}_{4} \mathrm{~g}^{-1} \mathrm{VS}_{\text {substrate }}$ for $2.0 \%$ TS. The digested sludge from the wastewater treatment plant led to the lowest lag-phase period and higher methane potential rate.
\end{abstract}

(c) 2012 Elsevier Ltd. All rights reserved.

\section{Introduction}

The possible uses and processing rules of animal by-products not intended for human consumption were defined by the European Parliament and the Council in October 2002 (Regulation (EC)1774, 2002). There are 3 categories of animal by-products $(A B P)$ : Category 1 is a high risk material; Category 3 is low risk ABP that are not intended for human consumption but can be used as a raw matter for animal feeds; and Category 2 that comprises all ABP included neither in Category 1 nor in Category 3. Category 2 includes (Kirchmayr et al., 2003): manure and digestive tract content; all animal materials collected when treating wastewater from slaughterhouses; products of animal origin containing residues of veterinary drugs; products of animal origin imported from EU non-member countries that fail to comply with the veterinary requirements into the Community; killed or fallen animals and so-

\footnotetext{
* Corresponding author. Tel.: +351 22 5081683; fax: +351225081449

E-mail address: bventura@fe.up.pt (R.A.R. Boaventura).
}

lid materials from slaughterhouses (particle size $>6 \mathrm{~mm}$ ), including animals killed to eradicate episodic diseases.

Currently, in Portugal, Category 2 ABP other than manure, digestive tract and milk are pre-cooked at around $100{ }^{\circ} \mathrm{C}$ (rendering process) and sterilized (designed as Category $2 \mathrm{ABP}^{*}$ hereafter) and then disposed in landfill. The sterilization of Category $2 \mathrm{ABP}$ is based on the reduction of the residue fraction to the particles with size $<50 \mathrm{~mm}$, sterilization at temperatures higher than $133^{\circ} \mathrm{C}$, for at least $20 \mathrm{~min}$ without interruption, at 3 bar absolute pressure, and marking the transformed residue with odorous repellent (smell). Due to the high organic matter content of Category $2 \mathrm{ABP}$, there is a great potential for the valorization of this residue through conversion into biogas by an anaerobic digestion process.

The use of different waste dilutions in determining the Biochemical Methane Potential (BMP) allows to check if the methane production is not underestimated (Angelidaki et al., 2009). According to these authors, when the maximum methane potential is the same in at least two consecutive dilutions of the dilution series, it can be assumed that the inoculum is neither overloaded nor 
Table 1

Composition of the substrate (Category $2 \mathrm{ABP}^{*}$ ) and inocula.

\begin{tabular}{|c|c|c|c|c|c|}
\hline \multicolumn{2}{|l|}{ Parameter \pm SE } & \multicolumn{3}{|c|}{ Exp 1} & Exp 2 \\
\hline \multicolumn{6}{|c|}{ Category $2 A B P^{*}$} \\
\hline \multicolumn{3}{|c|}{ Total solids (TS), $\mathrm{mg} \mathrm{g}^{-1}$ substrate } & \multicolumn{2}{|l|}{$916 \pm 1$} & $850 \pm 9$ \\
\hline \multicolumn{3}{|c|}{ Volatile solids (VS), $\mathrm{mg} \mathrm{g}^{-1} \mathrm{TS}$} & \multicolumn{2}{|l|}{$904 \pm 5$} & $766 \pm 36$ \\
\hline \multicolumn{3}{|c|}{ Total Kjeldahl Nitrogen (TKN), $\mathrm{mg} \mathrm{N} \mathrm{g}^{-1} \mathrm{TS}$} & \multicolumn{2}{|l|}{$84 \pm 9$} & $75 \pm 1$ \\
\hline \multicolumn{3}{|c|}{ Total phosphorus (TP), $\mathrm{mg} \mathrm{P} \mathrm{g}^{-1} \mathrm{TS}$} & \multicolumn{2}{|l|}{$6.2 \pm 0.9$} & $9.2 \pm 0.5$ \\
\hline \multicolumn{3}{|c|}{ Chemical oxygen demand (COD), $\mathrm{mg} \mathrm{O}_{2} \mathrm{~g}^{-1}$ TS } & \multicolumn{2}{|l|}{$1221 \pm 173$} & $1510 \pm 10$ \\
\hline \multicolumn{3}{|c|}{ Oil and grease $(\mathrm{O} \& \mathrm{G}), \mathrm{mg} \mathrm{g}^{-1} \mathrm{TS}$} & \multicolumn{2}{|l|}{$278 \pm 2$} & $374.1 \pm 0.6$ \\
\hline \multicolumn{3}{|c|}{$\mathrm{pH}$} & \multicolumn{2}{|l|}{5.4} & 6 \\
\hline \multicolumn{3}{|l|}{$\mathrm{COD} / \mathrm{N} / \mathrm{P}$} & \multicolumn{2}{|l|}{$197 / 14 / 1$} & $164 / 8 / 1$ \\
\hline \multirow[t]{2}{*}{ Parameter \pm SE } & \multicolumn{2}{|l|}{ DSWW } & \multirow[t]{2}{*}{ UASB } & MSWL & SAL \\
\hline & Exp 1 & Exp 2 & & Exp 2 & \\
\hline \multicolumn{6}{|l|}{ Inocula } \\
\hline Total solids (TS), $\mathrm{g} \mathrm{L}^{-1}$ & $17.71 \pm 0.09$ & $59.3 \pm 0.4$ & $121 \pm 4$ & $22.33 \pm 0.02$ & $7.71 \pm 0.04$ \\
\hline \multirow[t]{2}{*}{ Volatile solids (VS), $\mathrm{g} \mathrm{L}^{-1}$} & $11.68 \pm 0.06$ & $28.0 \pm 0.3$ & $43 \pm 4$ & $7.02 \pm 0.07$ & $5.34 \pm 0.03$ \\
\hline & $0.5 \%$ TS: 2.1 & & & & \\
\hline \multirow[t]{2}{*}{$\mathrm{ISR}^{*}\left(\mathrm{VS}_{\text {inoculum }} / \mathrm{VS}_{\text {substrate }}\right)$} & 2.0\%TS: 0.5 & 2.0\%TS: 1.3 & 2.0\%TS: 2.0 & 2.0\%TS: 0.3 & 2.0\%TS: 0.2 \\
\hline & 5.0\%TS: 0.2 & & & & \\
\hline
\end{tabular}

DSWW-digested sludge from a wastewater treatment plant.

UASB-granular sludge from an upflow anaerobic sludge blanket reactor.

MSWL-pre-concentrated leachate from a municipal solid waste landfill.

SAL-pre-concentrated sludge from a slaughterhouse anaerobic lagoon.

Inoculum/substrate ratio.

inhibited by the substrate. If the specific potential continues to increase with increasing dilution (then decreasing the substrate concentration), additional dilutions are required. High lipid and protein concentration in the Category $2 \mathrm{ABP}^{*}$ may cause inhibitory effects in biogas production. Palatsi et al. (2011) also reported a slow hydrolysis rate for this type of waste. The use of an inoculum adapted to high lipid and protein concentrations may reveal a good performance and a reduced start-up time for biogas production from ABP, as found by Gonçalves et al. (2011) that obtained higher biodegradation rate and accelerated anaerobic digestion start-up for olive mill wastewater, with biomass previously acclimatized to oleate. The inoculum source provides different microbial populations and adaptability to the substrate (Forster-Carneiro et al., 2007; Gonçalves et al., 2011; Moreno-Andrade and Buitrón, 2004). Recently, it was concluded that the slow lipid degradation rates and the need for specific enrichment of syntrophic microorganisms in the microbial community can be considered the main limiting factors for a successful anaerobic treatment of slaughterhouse waste mixtures (Palatsi et al., 2011). It is then convenient to find the best inoculum source, having the most adapted microorganisms for the anaerobic digestion of a specific residue (Angelidaki and Sanders, 2004). Typical inoculum sources for anaerobic digestion studies include: sludge from anaerobic digester for the treatment of pig manure (Lozano et al., 2009); swine excrement, corn silage, restaurant waste digested mixed with rice hulls, cattle excrement, swine excrement mixed with anaerobically digested sludge from municipal wastewater treatment plants (Forster-Carneiro et al., 2007), granular sludge from anaerobic reactor treating brewery effluent (Neves et al., 2004) and more frequently, digested sludge from anaerobic digesters of municipal wastewater treatment plants (Forster-Carneiro et al., 2007; Lee et al., 2009; Lozano et al., 2009). Nevertheless, the microorganisms in contact with the substrate will adapt or undergo a natural selection process and, with time, the remaining microorganisms in the reactor are already adapted to the substrate (Gonçalves et al., 2011). The selection of the inoculum - substrate ratio (ISR) as well as the assessment of anaerobic biodegradability of the solid waste is also crucial (Fernandez et al., 2001). In this perspective, the aim of the present work is to determine the BMP of Category $2 \mathrm{ABP}^{*}$ at mesophilic conditions and test different inocula sources to select the more suitable one to start-up a continuous reactor.

\section{Methods}

\subsection{Substrate}

The substrate was provided by a processing plant for Category 2 ABP. At the premises of the company, Category $2 \mathrm{ABP}$ is discharged into hoppers that combine soft offal and bone. The by-products are sized by crushing to reduce particle size to no more than $30 \mathrm{~mm}$ in diameter. Once sized, the material is transferred to a steam-heated vessel that agitates and pre-cooks the material at $101-104^{\circ} \mathrm{C}$ (rendering process) and then is conveyed for batch sterilization, at temperature of $140{ }^{\circ} \mathrm{C}, 3 \mathrm{bar}$ of pressure, during 20-25 min. The finished product (Category $2 \mathrm{ABP}^{*}$ ) is a fine granular material that is medium to light brown in color. For studying the effect of the total solids concentration and inoculum source on biogas production, two samples of Category $2 \mathrm{ABP}^{*}$ were collected at different times at the premises of the company, for carrying out each experiment. The physical-chemical characteristics of both samples are not very different, as shown in Table 1.

\subsection{Inoculum}

The inocula used in this study were digested sludge from a wastewater treatment plant (DSWW); granular sludge from an upflow anaerobic sludge blanket reactor (UASB); pre-concentrated leachate from a municipal solid waste landfill (MSWL) and preconcentrated sludge from a slaughterhouse anaerobic lagoon (SAL). All the inocula sources were composed of mixed anaerobic (methanogenic) communities with a specific methanogenic activity higher than $0.1 \mathrm{~g}$ COD- $\mathrm{CH}_{4} / \mathrm{gVSS}$.d.

DSWW was collected at the outlet of a suspended sludge anaerobic digester of a WWTP in Oporto, Portugal. The digester operates at $35^{\circ} \mathrm{C}$ and the hydraulic retention time is about 20 days. The granular sludge was kindly supplied by IBB - Institute for Biotechnology and Bioengineering, Centre of Biological Engineering, University of Minho, Portugal and was collected from an UASB reactor treating a brewery effluent. The municipal solid waste leachate was obtained in a sanitary landfill in Oporto, Portugal, before undergoing any treatment. The sludge from a slaughterhouse wastewater treatment anaerobic lagoon was collected at about $5 \mathrm{~m}$ depth, in Barcelos, Portugal. 
All the inocula were degassed by incubation at $35^{\circ} \mathrm{C}$, until gas production stopped. Diluted inocula were concentrated as follows: the leachate was centrifuged at $4000 \mathrm{rpm}$ during $15 \mathrm{~min}$, and the sludge from a slaughterhouse anaerobic lagoon was left to settle for $15 \mathrm{~min}$ and then the supernatant was rejected. The concentrated leachate (MSWL) and the settled slaughterhouse sludge (SAL) were then used in the experiments. Table 1 presents the total and volatile solids contents of the inocula and the ISR used in the BMP assays.

\subsection{Experimental procedure}

Biodegradability tests for evaluating the methane potential of Category $2 \mathrm{ABP}^{*}$ (Experiment 1 ) were performed for different values of ISR $(0.2,0.5$ and 2.1$)$ by varying the concentration of substrate from $0.5 \%$ to $5.0 \%$ TS (wt./vol.) and keeping constant the amount of inoculum used (DSWW). Taking into account the results from this experiment, a substrate content of $2.0 \%$ TS was selected to ensure non-inhibitory conditions in terms of nutrient limitations and toxic compounds concentration (Hansen et al., 2004) in Experiment 2, where four different inoculum sources were compared.

The amounts of $0.5,2$ and $5 \mathrm{~g}$ TS of substrate were transferred to glass bottles and then a volume of ca. $70 \mathrm{~mL}$ of inoculum. After the addition of $0.5 \mathrm{~g}$ of sodium bicarbonate, distilled water was added to glass bottles to perform $99.2 \mathrm{~mL}$. Blank tests were made without substrate, maintaining the other conditions. Bottles were closed with butyl rubber stoppers (RubberBv, Netherlands) and sealed with aluminum screw caps (Fischer Scientific, Netherlands). The headspace was flushed with $\mathrm{N}_{2} / \mathrm{CO}_{2}(80 / 20 \% \mathrm{v} / \mathrm{v})$ and $0.8 \mathrm{~mL}$ of $0.125 \mathrm{M} \mathrm{Na}_{2} \mathrm{~S}$ was injected (performing a final working volume of $100 \mathrm{~mL}$ ). The bottles were placed in a thermostatic room at $35 \pm 1{ }^{\circ} \mathrm{C}$ without stirring. The tests ended when the cumulative methane production reached a steady state. The methane concentration was measured during the test by gas chromatography thermal conductivity detector (GC-TCD; Experiment 1 ) and flame ionization detector (GC-FID; Experiment 2). The volume of methane produced was calculated by the ideal gas equation and converted to standard temperature and pressure (STP) $\left(0{ }^{\circ} \mathrm{C}\right.$ and $1 \mathrm{~atm}$ ) conditions.

\subsection{Analytical methods}

Total solids (TS) and volatile solids (VS) were determined according to (APHA et al., 2005): method 2540B for Total Solids Dried at $103-105^{\circ} \mathrm{C}$ and $2540 \mathrm{E}$ for Fixed and Volatile Solids Ignited at $550{ }^{\circ} \mathrm{C}$. The oil and grease was determined by the method 5220 D. Soxhlet Extraction Method (APHA et al., 1998). The pH was measured using a pH meter (Hanna Instruments model HI8424). Total Kjeldahl Nitrogen (TKN) was quantified according to ISO 5983-1 (IPQ 2007). Total phosphorus (TP) was determined, after digestion with ammonium persulfate (Method 4500-P B. Sample Preparation), by the ascorbic acid method (APHA et al., 2005). The Chemical Oxygen Demand (COD) was determined by the closed reflux colorimetric test (Merck test kit, 500-10,000 mg $\mathrm{O}_{2} \mathrm{~L}^{-1}$ ). In Experiment 1 , the methane concentration was determined by gas chromatography using a Porapack Q (180 to 100 Mesh) column, with helium as carrier gas at $30 \mathrm{~mL} \mathrm{~min}^{-1}$ and a TCD. The temperatures were adjusted to $35^{\circ} \mathrm{C}$ for the oven, $110^{\circ} \mathrm{C}$ for the injector and $110^{\circ} \mathrm{C}$ for the detector. The gas sample $(500 \mu \mathrm{L})$ was injected with a pressure lock syringe (Hamilton, Switzerland). In Experiment 2, methane was determined by GC-FID using a $30 \mathrm{~m} \times 0.53 \mathrm{~mm} \times$ $0.45 \mu \mathrm{m}$ Nukol capillary column. Helium was used as carrier and auxiliary gas. The carrier gas flow was $3 \mathrm{~mL} \mathrm{~min}^{-1}$. The temperatures were set at $40{ }^{\circ} \mathrm{C}$ for the oven, $120^{\circ} \mathrm{C}$ for the injector and

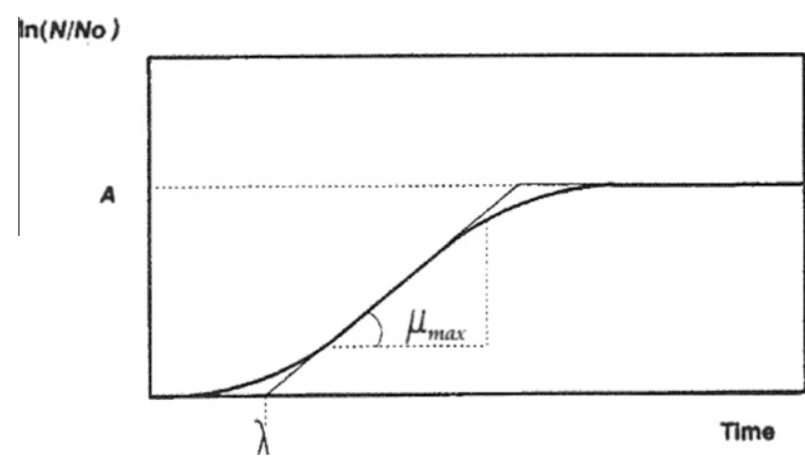

Fig. 1. Modified Gompertz growth curve (Eq. (1)) (Zwitering et al., 1990).

$130{ }^{\circ} \mathrm{C}$ for the detector. The sample $(100 \mu \mathrm{L})$ was injected as in the GC-TCD.

\subsection{Modeling}

The Gompertz equation applied to the modeling of bacterial growth curve can be written as (Lay et al., 1997):

$N(t)=\int_{0}^{t} r_{g} d t=A \cdot \exp \left\{-\exp \left[\frac{\mu_{\max } \cdot e}{A}(\lambda-t)+1\right]\right\}$

where $\mathrm{N}(\mathrm{t})$ is the amount of biomass at time $\mathrm{t}\left(\mathrm{mg} \mathrm{L}^{-1}\right), \mathrm{r}_{\mathrm{g}}$ is the bacterial growth rate $\left(\mathrm{mg} \mathrm{L}^{-1} \mathrm{~d}^{-1}\right), A=\ln \left(\mathrm{N}_{\infty} / \mathrm{N}_{0}\right)$, with $\mathrm{N}_{0}$ to $\mathrm{N}_{\infty}$, respectively, the initial amount of biomass and the limit value $\left(\mathrm{N}_{0} \rightarrow \mathrm{N}_{\infty}\right.$ when $\left.\mathrm{t} \rightarrow \infty\right), \mu_{\max }$ the maximum specific growth rate $\left(\mathrm{mg} \mathrm{L}^{-1} \mathrm{~d}^{-1}\right), \lambda$ the lag time (day) defined as the $x$-axis intercept of the tangent in the inflection point of the growth curve and $e$ the Neper's number. The physical meaning of $\mathrm{A}, \lambda$ and $\mu_{\max }$ may be visualized in Fig. 1 .

Taking into account the relationship between the bacterial growth rate $(\mathrm{rg})$ and the substrate utilization rate $(-\mathrm{rs}, \mathrm{mg}$ COD L $\mathrm{L}^{-1} \mathrm{~d}^{-1}$ ), with biological yield $\mathrm{Y}_{1}$, and the relationship between $-\mathrm{rs}$ and the methane production rate (rm, mg $\mathrm{COD}-\mathrm{CH}_{4}$ $\left.\mathrm{L}^{-1} \mathrm{~d}^{-1}\right)$, with methane yield $1 / \mathrm{Y}_{2}$, the cumulative production of methane $\left(\mathrm{M}, \mathrm{mg} \mathrm{COD}-\mathrm{CH}_{4}\right)$ can be calculated as

$M(t)=\int_{0}^{t} r_{m} d t=\int_{0}^{t} \frac{r_{g}}{Y_{1} Y_{2}} d t=\frac{1}{Y_{1} Y_{2}} \int_{0}^{t} r_{g} d t$

Or, replacing $\int_{0}^{t} r_{g} d t$ by the second term of Eq. (1),

$M(t)=\frac{A}{Y_{1} Y_{2}} \exp \left\{\exp \left[\frac{\left(\mu_{\max } / Y_{1} Y_{2}\right) e}{\left(A / Y_{1} Y_{2}\right)}(\lambda-t)+1\right]\right\}$

The term $A / Y_{1} Y_{2}$ may be replaced by $\mathrm{P}$ and can be interpreted as the potential for methane production (mg COD- $\mathrm{CH}_{4} \mathrm{~L}^{-1}$ ), and term $\mu_{\max } / Y_{1} Y_{2}$ means the maximum methane production rate (Rmax, $\mathrm{mg}$ COD- $\mathrm{CH}_{4} \mathrm{~L}^{-1} \mathrm{~d}^{-1}$ ).

Therefore the final expression derived from the modified Gompertz equation and used to calculate the cumulative production of methane is

$M(t)=P \cdot \exp \left\{-\exp \left[\frac{R_{\max } \cdot e}{P}(\lambda-t)+1\right]\right\}$

The experimental results of the cumulative methane production at time $t\left(\mathrm{~mL} \mathrm{CH}_{4}\right.$ per gram of substrate (VS) added to the digester) were fitted to the modified Gompertz equation (Zwitering et al., 1990). The parameters $\mathrm{P}\left(\mathrm{mL} \mathrm{CH}_{4} \mathrm{~g}^{-1} \mathrm{VS}_{\text {substrate }}\right), \mathrm{R}_{\max }\left(\mathrm{mL} \mathrm{CH}_{4} \mathrm{~g}^{-1}\right.$ $\mathrm{VS}_{\text {substrate }} \mathrm{day}^{-1}$ ) and $\lambda$ (day) were estimated by non-linear regression using the Solver function of the Microsoft Excel software by minimizing the residual sum of squared errors between the mean values of the experimental data and the model curve. 

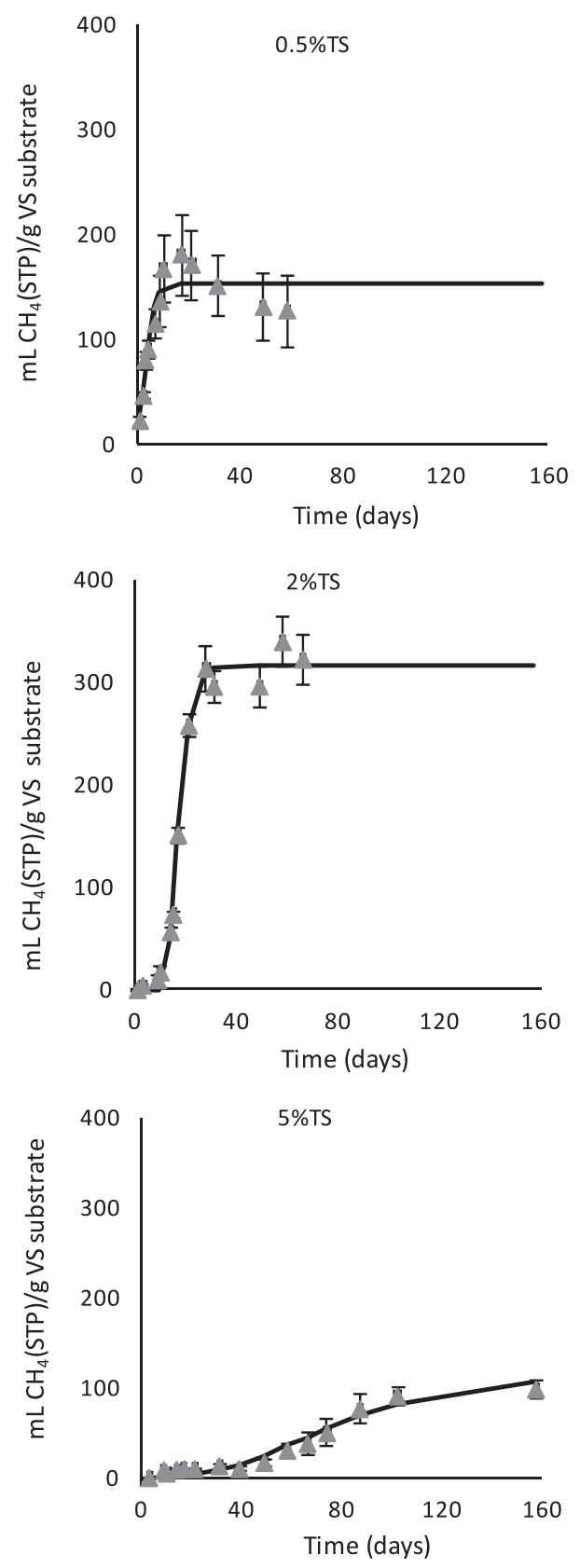

Fig. 2. Cumulative methane production $\left(\mathrm{mL} \mathrm{CH}\right.$ (STP, $0{ }^{\circ} \mathrm{C}$ and $\left.1 \mathrm{~atm}\right) \mathrm{g}^{-1}$ $\left.\mathrm{VS}_{\text {substrate }}\right)$ for $0.5 \%, 2 \%$ and $5 \%$ TS substrate: $\Delta$ Experimental data, - Modified Gompertz Model.
The modified Gompertz model has been used by several authors to describe the methane production in batch systems, from different organic substrates (Behera et al., 2010; Budiyono et al., 2010; Gadhamshetty et al., 2010; Lay et al., 1997; Li et al., 2012; Nopharatana et al., 2007; Shin et al., 2008; Wu et al., 2011).

\section{Results and discussion}

\subsection{Potential for mesophilic anaerobic digestion of Category $2 A B P^{*}$}

Category $2 \mathrm{ABP}^{*}$ potential for anaerobic digestion was assessed by studying the conversion to methane of aqueous suspensions of substrate containing $0.5 \%, 2.0 \%$ and $5.0 \%$ TS (Experiment 1). The suspensions of $0.5 \%, 2.0 \%$ and $5.0 \%$ TS are equivalent to approximately $6000,25,000$ and $60,000 \mathrm{mg} \mathrm{COD} \mathrm{L}^{-1}$. The cumulative methane production along time, normalized by the VS content of the substrate, is presented in Fig. 2, affected by the standard error. The values of $P, R_{\max }$ and $\lambda$, obtained by fitting the modified Gompertz model (Eq. (4)) to the experimental results, are shown in Table 2 . The run with a concentration of $0.5 \%$ TS shows methane production shortly after the test was started, i.e. without lag period, whereas for $2.0 \%$ and $5.0 \%$ TS the methane production started after 12 and 28 days, respectively. The volume of methane produced per gram of $\mathrm{VS}_{\text {substrate }}$ added (parameter $\mathrm{P}$ ) significantly increased by $51 \%$ when the TS concentration in the digester was changed from $0.5 \%$ to $2.0 \%$, but strongly decreased for the TS content of $5.0 \%$. The poorer result obtained for P when using $0.5 \%$ TS is probably due to the presence of some essential micronutrients for the microorganisms in concentrations below the required ones, or to the heterogeneity of the substrate, which contains, in addition to organic matter, bone particles, eggshells, etc. The value of $R_{\max }$ is not much different when the concentration of TS increases from $0.5 \%$ to $2.0 \%$ but sharply decreases for TS $=5.0 \%$. The slightly higher value for $R_{\max }$ obtained for $2.0 \%$ TS compared to $0.5 \%$ TS, means that the inoculum used (DSWW) is neither overloaded nor inhibited by $0.5 \%$ and $2.0 \% \mathrm{TS}$. The $\mathrm{P}$ and $\mathrm{R}_{\max }$ values for the highest concentration of TS (5.0\%) were markedly reduced ( $\mathrm{P}$ and $\mathrm{R}_{\max }$ are $64 \%$ and $97 \%$ below the potential obtained for $2.0 \%$ TS) revealing overload or strong inhibition of the inoculum. Hejnfelt and Angelidaki (2009) studied the anaerobic biodegradability of 5\%, 20\%, $50 \%$ and $100 \%$ (weight basis) pig slaughterhouse $\mathrm{ABP}$ at $55^{\circ} \mathrm{C}$ and used thermophilically digested manure from a centralized biogas plant as inoculum. Bone flour was the waste used in Hejnfelt's study, with characteristics similar to Category $2 \mathrm{ABP}^{*}$ of the present study. This author reported a cumulative methane production of $250 \mathrm{~mL} \mathrm{CH}_{4} \mathrm{~g}^{-1} \mathrm{VS}_{\text {substrate }}$ for $5.0 \%$ TS concentration, after 18 days of incubation. This higher production, compared with that obtained in the present study, can be due to the operation in the

Table 2

Modified Gompertz model parameters (value \pm SE) estimated for $0.5 \%, 2 \%$ and $5 \%$ TS of substrate (this study) and obtained for other substrates.

\begin{tabular}{|c|c|c|c|c|c|}
\hline Substrate & $\mathrm{P}\left(\mathrm{mL} \mathrm{CH} \mathrm{CH}_{4}(\mathrm{STP}) \mathrm{g}^{-1} \mathrm{VS}_{\text {substrate }}\right)$ & $\mathrm{R}_{\max }\left(\mathrm{mL} \mathrm{CH} \mathrm{CH}_{4}(\mathrm{STP}) \mathrm{g}^{-1} \mathrm{VS}_{\text {substrate }} \mathrm{d}\right)$ & $\lambda(\mathrm{d})$ & $\mathrm{R}^{2}$ & Reference \\
\hline MSW (insoluble fraction) & $210 \pm 10$ & $44 \pm 1$ & $0.7 \pm 0.2$ & - & Nopharatana et al. (2007) \\
\hline Swine manure & 492.36 & 21.43 & 5.68 & 0.997 & Shin et al. (2008) \\
\hline Restaurant food waste & 544.52 & 24.29 & 24.29 & 0.995 & Shin et al. (2008) \\
\hline Cattle manure + rumen fluids $(1: 1)$ & $172.51 \pm 6.64$ & $3.89 \pm 0.28$ & $7.3 \pm 1.7$ & 0.998 & Budiyono et al. (2010) \\
\hline Cattle manure + water $(1: 1)$ & $73.81 \pm 4.01$ & $1.74 \pm 0.13$ & $14.8 \pm 2.9$ & 0.999 & Budiyono et al. (2010) \\
\hline Food waste leachate $($ ISR $=1.0)$ & 314.2 & 9.03 & 14.0 & 0.992 & Behera et al. (2010) \\
\hline Food waste leachate $($ ISR $=0.2)$ & 218.6 & 7.10 & 16.4 & 0.988 & Behera et al. (2010) \\
\hline Grass-Pennisetum hybrid $($ ISR $=1.48)$ & 184.17 & 14.03 & 0 & 0.990 & Li et al. (2012) \\
\hline $\mathrm{ABP} * 0.5 \% \mathrm{TS}(\mathrm{ISR}=2.1)$ & $154 \pm 8$ & $24 \pm 7$ & $0.1 \pm 0.9$ & 0.884 & This study \\
\hline $\mathrm{ABP}^{*} 2 \% \mathrm{TS}(\mathrm{ISR}=0.5)$ & $317 \pm 7$ & $35 \pm 4$ & $12.5 \pm 0.5$ & 0.992 & This Study \\
\hline $\mathrm{ABP}^{*} 5 \% \mathrm{TS}(\mathrm{ISR}=0.2)$ & $114 \pm 11$ & $1.2 \pm 0.2$ & $28 \pm 5$ & 0.956 & This Study \\
\hline
\end{tabular}



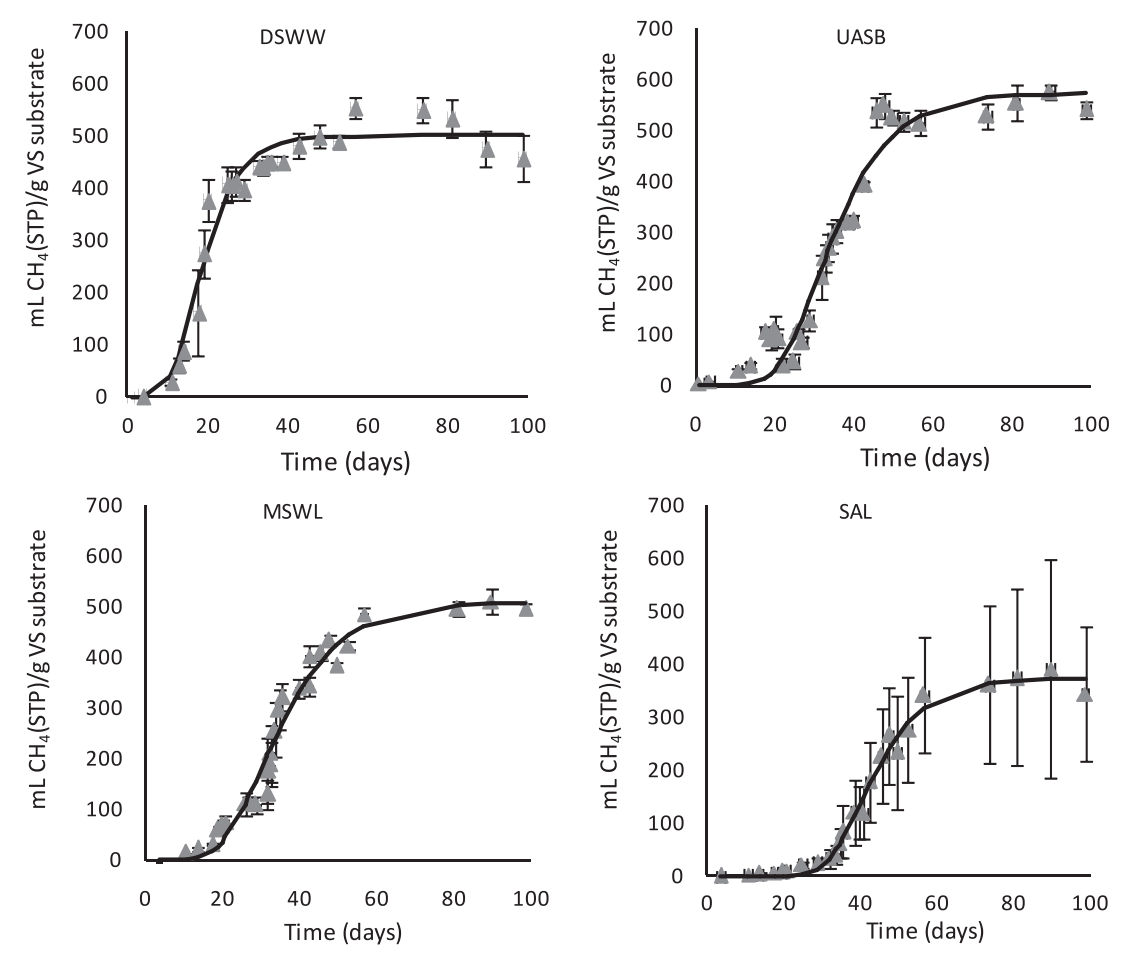

Fig. 3. Cumulative methane production per gram of substrate $\left(\mathrm{mL} \mathrm{CH}_{4}\left(\mathrm{STP}, 0{ }^{\circ} \mathrm{C}\right.\right.$ and $\left.\left.1 \mathrm{~atm}\right) \mathrm{g}^{-1} \mathrm{VS}_{\text {substrate }}\right)$ for $2 \% \mathrm{TS}$ substrate using different inocula: $\boldsymbol{\Delta}$ Experimental data, - Modified Gompertz Model.

Table 3

Modified Gompertz Model parameters (value \pm SE) estimated for anaerobic digestion of $2 \%$ TS substrate using different inocula (DSWW, UASB, MSWL, SAL).

\begin{tabular}{|c|c|c|c|c|}
\hline Parameter \pm SE & DSWW & UASB & MSWL & SAL \\
\hline $\mathrm{P}\left(\mathrm{mL} \mathrm{CH}_{4}(\mathrm{STP}) \mathrm{g}^{-1} \mathrm{VS}_{\text {substrate }}\right)$ & $500 \pm 14$ & $573 \pm 22$ & $509 \pm 18$ & $374 \pm 9$ \\
\hline $\mathrm{R}_{\max }\left(\mathrm{mL} \mathrm{CH}_{4}(\mathrm{STP}) \mathrm{g}^{-1} \mathrm{VS}_{\text {substrate }} \mathrm{d}^{-1}\right)$ & $30 \pm 4$ & $21 \pm 2$ & $17 \pm 1$ & $15 \pm 1$ \\
\hline$\lambda(\mathrm{d})$ & $10 \pm 1$ & $21 \pm 1$ & $20 \pm 1$ & $30.8 \pm 0.7$ \\
\hline Determination coefficient $\left(\mathrm{R}^{2}\right)$ & 0.966 & 0.957 & 0.969 & 0.988 \\
\hline $\mathrm{P}\left(\mathrm{mL} \mathrm{CH}_{4}(\mathrm{STP}) \mathrm{g}^{-1} \mathrm{VS}_{\text {inoc }} \mathrm{g}^{-1} \mathrm{VS}_{\text {subs }}\right)$ & $255 \pm 7$ & $189 \pm 7$ & $1059 \pm 27$ & $1033 \pm 26$ \\
\hline $\mathrm{R}_{\max }\left(\mathrm{mL} \mathrm{CH}_{4}(\mathrm{STP}) \mathrm{g}^{-1} \mathrm{VS}_{\text {inoc }} \mathrm{g}^{-1} \mathrm{VS}_{\text {subs }} \mathrm{d}^{-1}\right)$ & $15 \pm 2$ & $6.8 \pm 0.7$ & $33 \pm 2$ & $39 \pm 2$ \\
\hline$\lambda(\mathrm{d})$ & $10 \pm 1$ & $21 \pm 1$ & $19 \pm 1$ & $30.7 \pm 0.7$ \\
\hline Determination coefficient $\left(\mathrm{R}^{2}\right)$ & 0.966 & 0.957 & 0.982 & 0.989 \\
\hline
\end{tabular}

thermophilic regime, to the different inoculum source used or to small differences in the fat and protein contents of the substrates.

The BMP values obtained in this study are within the range of values (100-600 $\mathrm{mL} \mathrm{CH}_{4} \mathrm{~g}^{-1} \mathrm{VS}_{\text {substrate }}$ ) found for other substrates transformed by anaerobic digestion (Pesta, 2007). The Gompertz model parameters obtained for Category $2 \mathrm{ABP}^{*}(0.49 \%-4.9 \% \mathrm{VS})$ and substrates such as the insoluble fraction of MSW (1.6\% VS), swine manure (20.5\% VS), restaurant food waste (16.3\% VS), cattle manure and rumen fluids (10.5\% VS), diluted cattle manure $(9.7 \%$ VS), food waste leachate (10.8\% VS) and grass (13.72\% VS) are compared in Table 2. Category $2 \mathrm{ABP}^{*}$ with $2.0 \%$ TS led to one of the highest $R_{\max }$, an intermediate $P$ value and a relatively short lag time, $\lambda$. The highest potential for anaerobic digestion of this substrate occurred for ISR $=0.5$. Sri Bala Kameswari et al. (2012) studied the ISR effect on the anaerobic digestion of tannery solid wastes, in the range $0.25-2.3$, and obtained the best result for ISR $=1$. For lower values the methane yield significantly decreased and for higher ones the difference on methane performance was less than 5\%. For kitchen waste, Neves et al. (2004), obtained better results for ISR $=2$. The low ISR value obtained in this study indicates that Category $2 \mathrm{ABP}^{*}$ is a suitable substrate for anaerobic digestion.
3.2. Assessment of different inocula sources for anaerobic digestion of Category $2 A B P *$

Improvement of the anaerobic digestion of the Category $2 \mathrm{ABP} *$ was assessed by using four different inocula sources and a substrate concentration of $2.0 \%$ TS (Experiment 2). The cumulative methane production per gram of substrate (VS) along time is presented in Fig. 3, affected by the standard error. The modified Gompertz Model was adjusted to the experimental results and the model parameters are shown in Table 3. The highest values of $P$ were achieved for the inocula DSWW, UASB and MSWL. The lag time corresponding to inoculum DSWW was half of the time of UASB and MSWL. The longest start-up (31 days) was observed for SAL, and its average P value was the lowest one but when looking at the standard error, one of the flasks led to a $P$ value as high as those obtained with the other three inocula. The $R_{\max }$ value was higher for DSWW, followed by UASB, MSWL and SAL (Table 3). The pseudo-steady state was reached after 27, 49, 50 and 56 days, respectively, for DSWW, UASB, MSWL and SAL.

Fig. 4 shows the cumulative methane production per gram of substrate (VS) initially added, normalized by the initial VS of the inocula, following the procedure of Kim and Speece (2002) on their 

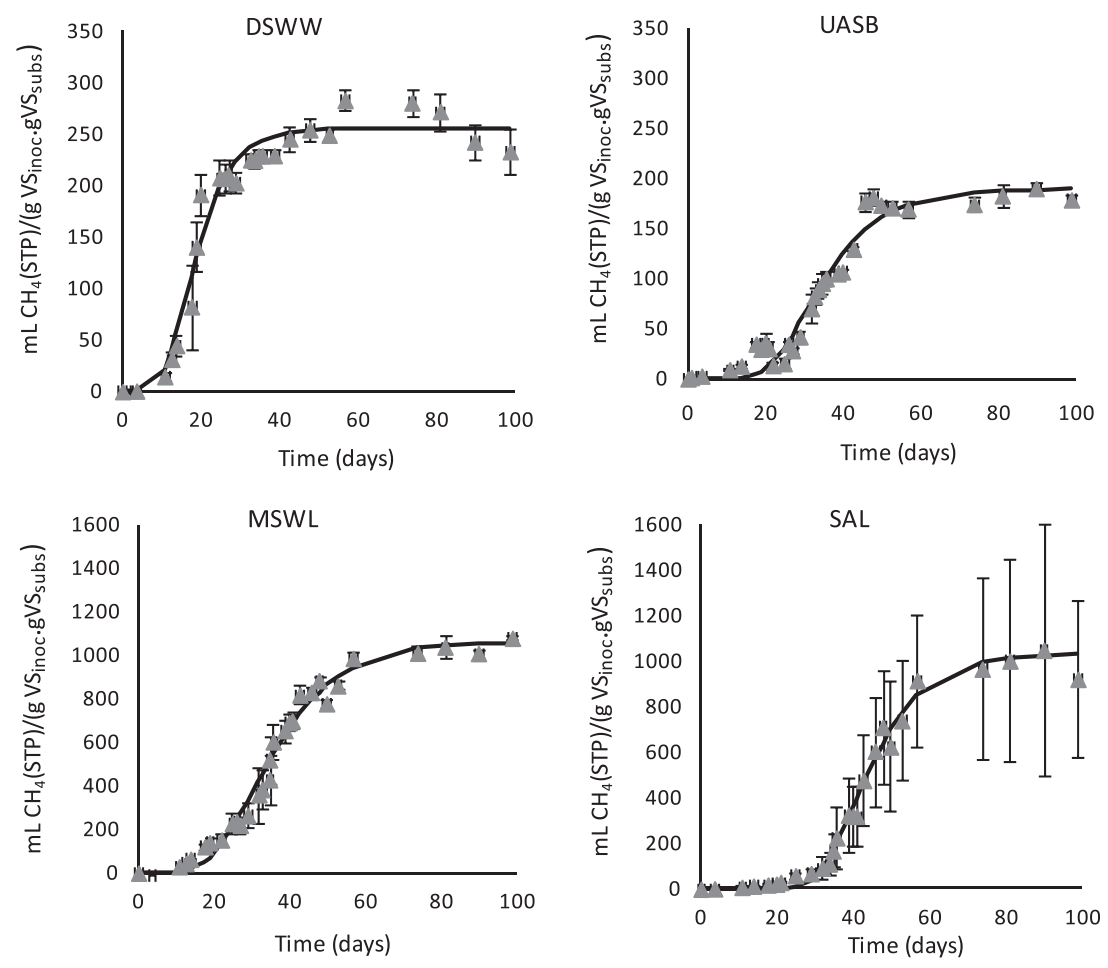

Fig. 4. Cumulative methane production normalized by VS of inoculum ( $\mathrm{mL} \mathrm{CH}$ (STP, $0{ }^{\circ} \mathrm{C}$ and $\left.\left.1 \mathrm{~atm}\right) \mathrm{g}^{-1} \mathrm{VS}_{\text {inoculum }} \mathrm{g}^{-1} \mathrm{VS}_{\text {substrate }}\right)$ for $2 \% \mathrm{TS}$ substrate using different inocula: \ Experimental data, — Modified Gompertz Model.

evaluation study of the start-up performance of anaerobic digestion using aerobic waste activated sludge $\left(4.4 \mathrm{~g} \mathrm{VS} \mathrm{L}^{-1}\right)$ and mesophilic anaerobic digested sludge (14.5 $\mathrm{g} \mathrm{VS} \mathrm{L}^{-1}$ ) as inoculum sources. MSWL and SAL showed higher P (1059 and $1033 \mathrm{~mL} \mathrm{CH}_{4}$ (STP) $\mathrm{g}^{-1} \mathrm{VS}_{\text {inoc }} \mathrm{g}^{-1} \mathrm{VS}_{\text {subs, }}$, respectively) and $\mathrm{R}_{\max }$ (33 and $39 \mathrm{~mL}$ $\mathrm{CH}_{4} \mathrm{~g}^{-1} \mathrm{VS}_{\text {inoc }} \mathrm{g}^{-1} \mathrm{VS}_{\text {subs }} \mathrm{d}^{-1}$, respectively), when compared with DSWW and UASB, which means that those inocula show a better and similar capacity to biodegrade Category $2 \mathrm{ABP}^{*}$ (Table 3 and Fig. 4). However, MSWL and SAL needed to be pre-concentrated to obtain higher ISR values. Using DSWW as inoculum source leads to a shorter start-up period but the potential for methane production and maximum production rate are lower after normalization by the initial VS content of the inoculum.

\section{Conclusions}

The maximum methane potential of Category $2 \mathrm{ABP}^{*}$ (317 $\pm 7 \mathrm{~mL} \mathrm{CH}_{4} \mathrm{~g}^{-1} \mathrm{VS}_{\text {substrate }}$ ) was achieved for a concentration of $2.0 \%$ TS using digested sludge from a WWTP as inoculum. A concentration of $0.5 \%$ TS is probably nutrient missing and the accumulation of inhibitory compounds is suspected to occur when using $5.0 \%$ TS. The digested sludge from a WWTP also led to a shorter lag time (10 days). Taking into account the initial VS concentration, the highest potential for methane production $(1059 \mathrm{~mL} \mathrm{CH}$ (STP) $\mathrm{g}^{-1} \mathrm{VS}_{\text {subs }} \mathrm{g}^{-1} \mathrm{VS}_{\text {inoc }}$ ) was achieved using leachate from a MSW sanitary landfill as inoculum source.

\section{Acknowledgements}

This work was partially supported by project PEst-C/EQB/ LA0020/2011, financed by FEDER through COMPETE - Programa Operacional Factores de Competitividade and by FCT - Fundação para a Ciência e a Tecnologia. FCT is acknowledged for the financial support given to Tatiana Pozdniakova through the PhD scholarship
(SFRH/BD/45144/2008) and José Carlos Costa through the grant (SFRH/BDP/48962/2008).

\section{References}

Angelidaki, I., Sanders, W., 2004. Assessment of the anaerobic biodegradability of macropollutants. Rev. Environ. Sci. Biotechnol. 3 (2), 117-129.

Angelidaki, I., Alves, M.M., Bolzonella, D., Borzacconi, L., Campos, J.L., Guwy, A.J., Kalyuzhnyi, S., Jenicek, P., Van Lier, J.B., 2009. Defining the biomethane potential (BMP) of solid organic wastes and energy crops: a proposed protocol for batch assays. Water Sci. Technol. 59 (5), 927-934.

APHA, Awwa, WEF, 1998. Standard Methods for the Examination of Water and Wastewater, 20th ed. American Public Health Association, Washington, D.C., EUA.

APHA, Awwa, WEF, 2005. Standard Methods for the Examination of Water and Wastewater, 21st ed. American Public Health Association, Washington, D.C., USA.

Behera, S.K., Park, J.M., Kim, K.H., Park, H.S., 2010. Methane production from food waste leachate in laboratory-scale simulated landfill. Waste Manage. (Oxford) 30 (8-9), 1502-1508.

Budiyono, Widiasa, I.N., Johari, S., Sunarso, 2010. The kinetic of biogas production rate from cattle manure in batch mode. Int. J. Chem. Biol. Eng. 3 (1), 39-44.

Fernandez, B., Porrier, P., Chamy, R., 2001. Effect of inoculum-substrate ratio on the start-up of solid waste anaerobic digesters. Water Sci. Technol. 44 (4), 103-108.

Forster-Carneiro, T., Pérez, M., Romero, L.I., Sales, D., 2007. Dry-thermophilic anaerobic digestion of organic fraction of the municipal solid waste: focusing on the inoculum sources. Bioresour. Technol. 98 (17), 3195-3203.

Gadhamshetty, V., Arudchelvam, Y., Nirmalakhandan, N., Johnson, D.C., 2010. Modeling dark fermentation for biohydrogen production: ADM1-based model vs. Gompertz model. Int. J. Hydrogen Energy 35 (2), 479-490.

Gonçalves, M.R., Costa, J.C., Marques, I.P., Alves, M.M., 2011. Inoculum acclimation to oleate promotes the conversion of olive mill wastewater to methane. Energy 36 (4), 2138-2141.

Hansen, T.L., Schmidt, J.E., Angelidaki, I., Marca, E., Jansen, J.L.C., Mosbæk, H., Christensen, T.H., 2004. Method for determination of methane potentials of solid organic waste. Waste Manage. (Oxford) 24 (4), 393-400.

Hejnfelt, A., Angelidaki, I., 2009. Anaerobic digestion of slaughterhouse by-products. Biomass Bioenergy 33 (8), 1046-1054.

IPQ 2007. Norma Portuguesa NP EN ISO 5983-1 Alimentos para animais Determinação do teor de azoto e cálculo do teor de proteína bruta - Parte 1: Método Kjeldahl. Instituto Português da Qualidade, Caparica, Portugal.

Kim, M., Speece, R.E., (2002). Aerobic waste activated sludge (WAS) for start-up seed of mesophilic and thermophilic anaerobic digestion. Water Res. 36 (15), 38603866. 
Kirchmayr, R., Scherzer, R., Baggesen, D.L., Braun, R., 2003. Animal by-Products and Anaerobic Digestion - Requirements of the European Regulation (EC) No 1774 2002. in: Energy from Biogas and Landfill Gas, IEA Bioenergy Task 37, European Commission Joint Research Centre, Petten, The Netherlands, pp. 24.

Lay, J.J., Li, Y.Y., Noike, T., 1997. Influences of pH and moisture content on the methane production in high-solids sludge digestion. Water Res. 31 (6), 1518 1524.

Lee, C., Kim, J., Hwang, K., O’Flaherty, V., Hwang, S., 2009. Quantitative analysis of methanogenic community dynamics in three anaerobic batch digesters treating different wastewaters. Water Res. 43 (1), 157-165.

Li, L., Kong, X., Yang, F., Li, D., Yuan, Z., Sun, Y., 2012. Biogas production potential and kinetics of microwave and conventional thermal pretreatment of grass. Appl. Biochem. Biotechnol. 166 (5), 1183-1191.

Lozano, C.J.S., Mendoza, M.V., de Arango, M.C., Monroy, E.F., 2009. Microbiologia characterization and specific methanogenic activity of anaerobe sludges used in urban solid waste treatment. Waste Manage. (Oxford) 2 (29), 704-711.

Moreno-Andrade, I., Buitrón, G., 2004. Influence of the origin of the inoculum on the anaerobic biodegradability test. Water Sci. Technol. 49 (1), 53-59.

Neves, L., Oliveira, R., Alves, M.M., 2004. Influence of inoculum activity on the biomethanization of a kitchen waste under different waste/inoculum ratios. Process Biochem. 39 (12), 2019-2024.

Nopharatana, A., Pullammanappallil, P.C., Clarke, W.P., 2007. Kinetic and dynamic modelling of batch anaerobic digestion of municipal solid waste in a stirred reactor. Waste Manage. (Oxford) 27 (5), 595-603.
Palatsi, J., Viñas, M., Guivernau, M., Fernandez, B., Flotats, X., 2011. Anaerobic digestion of slaughterhouse waste: main process limitations and microbial community interactions. Bioresour. Technol. 102 (3), 2219-2227.

Pesta, G., 2007. Anaerobic digestion of organic residues and wastes. In: Oreopoulou, V., Russ, W. (Eds.), Utilization of By-products and Treatment of Waste in the Food Industry. Springer, New York.

Regulation (EC)1774, 2002. European Community Regulation (EC) no 1774/2002 laying down health rules concerning animal by-products not intended for human consumption, European Parliament and of the Council of 3 October 2002.

Shin, J.D., Han, S.S., Eom, K.C., Sung, S., Park, S.W., Kim, H., 2008. Predicting methane production potential of anaerobic co-digestion of swine manure and food waste. Environ. Eng. Res. 13 (2), 93-37.

Sri Bala Kameswari, K., Kalyanaraman, C., Porselvam, S., Thanasekaran, K., 2012. Optimization of inoculum to substrate ratio for bio-energy generation in codigestion of tannery solid wastes. Clean Technol. Environ. Policy 14 (2), 241250.

Wu, D., Yang, Z., Tian, G., 2011. Inhibitory effects of Cu (II) on fermentative methane production using bamboo wastewater as substrate. J. Hazard. Mater. 195, 170174.

Zwitering, M.H., Jongenburger, I., Rombouts, F.M., van't Riet, K., 1990. Modeling of the bacterial growth curve. Appl. Environ. Microbiol. 56 (6), 1875-1881. 